\title{
PELATIHAN DAN PENDAMPINGAN PENULISAN ARTIKEL ILMIAH DI MTs MUHAMMADIYAH 1 MALANG
}

\author{
Arif Setiawan $^{1)}$, Gigit Mujianto ${ }^{2}$, Musaffak $^{3)}$ \\ ${ }^{122) 3)}$ Program Studi Pendidikan Bahasa Indonesia, Fakultas Keguruan dan Ilmu Pendidikan, \\ Universitas Muhammadiyah Malang, Malang, Indonesia
}

Corresponding Author: Arif Setiawan, arifsetiawan@umm.ac.id

\begin{abstract}
Abstrak: Menulis karya ilmiah merupakan kewajiban yang harus dilakukan oleh guru untuk memperkuat kompetensi profesionalnya, namun dalam realitasnya masih banyak guru yang belum melakukannya. Kegiatan pengabdian ini bertujuan untuk melakukan pelatihan dan pendampingan penulisan artikel ilmiah di MTs Muhammadiyah 1 Malang. Metodologi yang digunakan dalam kegiatan ini terdiri dari (1) sharing permasalahan penulisan artikel melalui pimpinan sekolah atau kepala sekolah dan guru, (2) ekspositori konsep, (3) pelatihan penulisan artikel, dan (4) pendampingan proses penulisan artikel, (5) evaluasi kegiatan, dan (6) kegiatan publikasi artikel di jurnal SAINTIFIK, milik Majelis Dikdasmen Pimpinan Daerah Muhammadiyah (PDM) Kabupaten Malang. Jumlah guru yang mengikuti kegiatan pelatihan dan pendampingan penulisan artikel ini sebanyak 15 orang. Berdasarkan hasil evaluasi kegiatan, dari 15 guru yang mengikuti kegiatan pelatihan dan pendampingan penulisan artikel ilmiah, 11 guru telah menyelesaikan tagihan artikel ilmiah, 3 yang sudah hampir menyelesaikan tagihan artikel ilmiah, serta 1 guru yang masih pada proses penulisan artikel bagian pembahasan/metode serta penutup/hasil dan pembahasan. Kegiatan pelatihan dan pendampingan penulisan artikel ilmiah ini, telah membantu guru MTs Muhammadiyah 1 Malang untuk menulis artikel ilmiah dalam bentuk artikel hasil pemikiran/kajian dan artikel hasil penelitian.
\end{abstract}

Kata Kunci: Artikel hasil pemikiran/kajian, Artikel ilmiah, Artikel hasil penelitian, Pelatihan dan Penulisan

Abstract: Writing scientific papers is an obligation that must be done by teachers to strengthen their professional competence. This service activity aims to conduct training and assistance in writing scientific articles at MTs Muhammadiyah 1 Malang. The methodology used in this activity consists of (1) sharing the problems of writing articles through school leaders or principals and teachers, (2) concept expository, (3) article writing training, and (4) article writing process assistance, (5) evaluation activities, and (6) publication of articles in the journal SAINTIFIK Volume 7 Number 2 of 2020, belonging to the Muhammadiyah Regional Leadership Educational Council (PDM) Malang Regency. The number of teachers who participated in the training and mentoring activities for writing this article was 15 people. Based on the results of the evaluation of activities, of the 15 teachers who participated in the training and mentoring of scientific article writing, 11 teachers had completed the scientific article bill, 3 had almost completed the scientific article bill, and 1 teacher was still in the process of writing the discussion/method and closing articles. /results and Discussion. This training activity and assistance in writing scientific articles has helped teachers of MTs Muhammadiyah 1 Malang to write scientific articles in the form of articles of thought/study and research articles.

Keywords: Articles of thought/study, Scientific articles, Research articles, Training and Writing

Submited: 30-07-2021 Revised 18-10-2021 Accepted: 22-10-2021 


\section{Pendahuluan}

Menulis karya ilmiah merupakan kewajiban yang harus dilakukan oleh guru, selain tugas utamanya mengajar (Ismail dkk, 2016). Keterampilan menulis yang dimiliki oleh guru merupakan salah satu kelebihan yang dimiliki oleh sebuah institusi. Selain itu, menulis karya ilmiah juga menjadi salah satu syarat wajib dalam mengurus kenaikan jabatan atau angka kredit (Aisyah dan Mahanani, 2017). Hal ini semakin meneguhkan Undang-Undang No. 14 Tahun 2005 mengenai Guru dan Dosen bahwa guru adalah sebuah profesi. Berdasarkan undangundang tersebut, guru harus terus mengembangkan kompetensi profesionalnya (Kasiyan dkk, 2019). Seorang guru dikatakan profesional apabila dalam melaksanakan tugas selalu berpedoman pada etika profesi, inovatif, kreatif, independen, dan berorientasi pada prinsip pelayanan prima berdasarkan bidang ilmu dan teori secara sistematis (Marlena dkk, 2017). Berdasarkan prinsip profesional tersebut, guru yang profesional tidak hanya dapat melakukan pelayanan secara prima, melainkan melakukan tugas profesional lainnya yang berkaitan dengan pengembangan kemampuan akademik yang dimilikinya, salah satunya melalui menulis karya ilmiah (Chairunnisa, 2016; Marlena dkk,., 2017). Hal ini merupakan potret ideal dan menjadi sebuah harapan dari setiap kepala sekolah (Arta, 2019).

Potret ideal yang diharapkan oleh setiap kepala sekolah merupakan suatu kewajiban yang harus diselenggarakan oleh sekolah (Ekosiswoyo, 2016). Selain itu, juga menjadi salah satu sektor yang harus terus dibenahi dan dikembangkan oleh setiap kepala sekolah, tak terkecuali kepala sekolah Muhammadiyah baik di tingkat dasar-menengah. Proses pembenahan dilakukan agar dapat mengubah stigma yang selama ini telah melekat di masyarakat, bahwa sekolah-sekolah Muhammadiyah spesialis juara lomba nonakademik. Berdasarkan kondisi tersebut, stigma yang selama ini telah melekat harus segera diluruskan dan dibenahi, sehingga tujuan pendidikan menjadi salah satu prioritas yang wajib diberikan pada semua pengguna sekolah/stakeholder (Martati dan Setyorini, 2019).

Tuntutan untuk terus berbenah tersebut dipandang sebagai salah satu kepastian yang harus dilakukan oleh sekolah Muhammadiyah. Oleh karena itu, sebagai salah satu cara untuk meningkatkan kompetensi profesional guru di sekolah Muhammadiyah perlu adanya kegiatan yang berorientasi pada peningkatan kompetensi guru. Berdasarkan kondisi tersebut, MTs Muhammadiyah 1 Malang perlu melakukan kerjasama dengan pihak perguruan tinggi untuk menguraikan benang kusut, sehingga kompetensi profesional guru khususnya dalam menulis artikel ilmiah semakin baik. Penulisan artikel ilmiah merupakan suatu hal yang menarik untuk dilakukan di MTs Muhammadiyah 1 Malang, dikarenakan menulis artikel ilmiah merupakan salah satu tugas yang harus dipenuhi guru untuk mengukur kinerja yang dilakukan (Ekosiswoyo, 2016). Selain itu, menulis artikel ilmiah merupakan salah satu indikator untuk mengukur kinerja guru yang tercantum dalam salah satu penilaian akreditasi sekolah, angka kredit, serta sertifikasi guru (Marlena dkk,., 2017). Sementara itu, guru-guru MTs Muhammadiyah 1 Malang masih belum secara keseluruhan memiliki motivasi untuk memroduksi artikel ilmiah (Aghittara, 2016), sehingga kondisi tersebut sedikit bertolak belakang dengan potret yang diharapkan oleh setiap kepala sekolah. Hal ini dikarenakan guru belum memiliki pengetahuan dan keterampilan menulis yang memadai dalam menulis artikel ilmiah (Chairunnisa, 2016). Berdasarkan kondisi tersebut, kegiatan pelatihan dan pendampingan menulis artikel ilmiah di MTs Muhammadiyah 1 Malang menjadi penting untuk dilakukan. Kegiatan pengabdian ini bertujuan melatih dan mendampingi guru MTS Muhammadiyah 1 Malang untuk melakukan kegiatan penulisan artikel ilmiah.

Kegiatan pengabdian sejenis telah banyak dilakukan sebelumnya (Arta, 2019), semua kegiatan pengabdian tersebut memfokuskan pada pelatihan penulisan artikel ilmiah dan proposal PTK. Kegiatan pengabdian dalam bentuk pelatihan dan pendampingan penulisan 
artikel ilmiah yang diterbitkan di Jurnal SAINTIFIK milik Pimpinan Daerah Muhammadiyah (PDM) Kabupaten Malang belum pernah dilakukan sebelumnya.

\section{Metode}

Sasaran kegiatan pengabdian kepada masyarakat ini adalah guru MTs Muhammadiyah 1 Malang. Adapun jumlah sasaran dalam kegiatan ini sebanyak 15 guru dari MTs Muhammadiyah 1 Malang. Lokasi MTs Muhammadiyah 1 Malang terletak di Jalan Baiduri Sepah No 27 Tlogomas Kota Malang. Kegiatan pelatihan dan pendampingan artikel ilmiah ini dilaksanakan di Laboratorium Komputer milik MTs Muhammadiyah 1 Malang.

Metodologi pelaksanaan dalam kegiatan pelatihan dan pendampingan penulisan artikel ilmiah di MTs Muhammadiyah 1 Malang terdiri dari enam kegiatan yang meliputi (1) sharing permasalahan penulisan artikel melalui pimpinan sekolah atau kepala sekolah dan guru, (2) ekspositori konsep, (3) pelatihan penulisan artikel, dan (4) pendampingan proses penulisan artikel, dan (5) evaluasi kegiatan, (6) kegiatan publikasi artikel di jurnal SAINTIFIK, milik Majelis Dikdasmen Pimpinan Daerah Muhammadiyah (PDM) Kabupaten Malang. Adapun masing-masing metode tersebut diuraikan dalam penjelasan berikut (Arta, 2019).

(1) Sharing permasalahan penulisan artikel melalui pimpinan sekolah atau kepala sekolah dan guru. Kegiatan ini bertujuan menggali informasi mengenai kondisi awal dan latar belakang dari masing-masing guru. Hasil sharing ini digunakan sebagai dasar dalam proses penulisan artikel, sehingga informasi yang didapatkan dapat dijadikan sebagai pijakan dalam melakukan pelatihan dan pendampingan penulisan artikel.

(2) Ekspositori konsep, kegiatan ini bertujuan untuk memberikan wawasan kepada para guru mengenai bagaimana mengembangkan ide yang dimiliki untuk menjadi draf artikel ilmiah yang akan ditulis.

(3) Pelatihan penulisan artikel ilmiah dilakukan sebanyak tiga kali dalam bentuk tatap muka (luring) dengan menerapkan protokol kesehatan sesuai anjuran pemerintah. Kegiatan tatap muka diwujudkan dalam bentuk pelatihan menulis artikel ilmiah yang diawali dengan menggali ide-ide yang telah dimiliki oleh guru untuk dijadikan topik dalam artikel. Selanjutnya, masing-masing guru mengembangkan ide sesuai dengan tata urutan dalam penulisan artikel ilmiah.

(4) Kegiatan pendampingan dilakukan pada masing-masing peserta yang telah mewujudkan ide menjadi draf artikel ilmiah. Selanjutnya dilakukan proses otokoreksi antarpeserta pelatihan untuk melihat kepaduan ide yang dituangkan dalam bentuk draf artikel ilmiah. Kegiatan dilanjutkan dengan proses revisi draf artikel ilmiah yang telah dilakukan otokoreksi antarpeserta. Setelah proses revisi yang telah dilakukan, peserta dapat melanjutkan penyusunan artikel sesuai dengan sistematika yang telah disampaikan oleh narasumber. Proses pendampingan untuk penyusunan artikel ilmiah dilakukan sebanyak tiga kali dalam bentuk tatap muka (luring) dengan menerapkan protokol kesehatan sesuai anjuran pemerintah.

(5) Kegiatan evaluasi diperlukan sebagai salah satu langkah untuk mengetahui sejauh mana pelaksanaan kegiatan pelatihan dan pendampingan artikel ilmiah ini berjalan sesuai dengan target yang telah ditetapkan.

(6) Kegiatan selanjutnya adalah publikasi artikel berdasarkan hasil pelatihan dan pendampingan penulisan artikel ilmiah dari 15 guru MTs Muhammadiyah 1 Malang.

Kegiatan pelatihan dan pendampingan penulisan artikel ilmiah dilaksanakan sebanyak sembilan kali dalam bentuk tatap muka secara langsung (luring) dengan menerapkan protokol kesehatan sesuai anjuran pemerintah. Adapun jadwal kegiatan secara detail dapat dilihat pada Tabel 1. 
Tabel 1. Jadwal Kegiatan Pelatihan dan Pendampingan Penulisan Artikel Ilmiah di MTs Muhammadiyah 1 Malang

\begin{tabular}{|c|c|c|c|c|}
\hline No & Tanggal & Kegiatan & Pelaksanaan & Pemateri \\
\hline 1 & 9 Mei 2020 & $\begin{array}{l}\text { Kegiatan sharing/berbagi Permasalahan } \\
\text { pembelajaran melalui kepala sekolah dan } \\
\text { guru. }\end{array}$ & Luring & Tim \\
\hline 2 & 23 Mei 2020 & $\begin{array}{l}\text { Ekspositori konsep dan paparan materi } \\
\text { mengenai: } \\
\text { 1. Pentingnya guru menulis artikel } \\
\text { ilmiah } \\
\text { 2. Tata cara penulisan artikel ilmiah } \\
\text { 3. Gaya selingkung artikel ilmiah } \\
\text { 4. Bagaimana cara membuat kutipan } \\
\text { dan daftar pustaka dengan tools } \\
\text { reference } \\
\end{array}$ & Luring & Tim \\
\hline 3 & 6 Juni 2020 & $\begin{array}{l}\text { Pelatihan penulisan artikel tentang } \\
\text { menulis Pendahuluan }\end{array}$ & Luring & Dr. Gigit Mujianto, M.Si \\
\hline 4 & 20 Juni 2020 & $\begin{array}{l}\text { Pelatihan penulisan } \\
\text { menulis Metode \& } \\
\text { Pembahasan }\end{array}$ & Luring & Musaffak, M.Pd. \\
\hline 5 & 4 Juli 2020 & $\begin{array}{l}\text { Pelatihan penulisan artikel tentang } \\
\text { menulis Simpulan, Daftar Pustaka, dan } \\
\text { Abstrak }\end{array}$ & Luring & Arif Setiawan, M.Pd \\
\hline 6 & 11 Juli 2020 & Pendampingan Proses Penulisan Artikel & Luring & Tim \\
\hline 7 & 18 Juli 2020 & Pendampingan Proses Penulisan Artikel & Luring & Tim \\
\hline 8 & 25 Juli 2020 & Pendampingan Proses Penulisan Artikel & Luring & Tim \\
\hline 9 & $\begin{array}{l}8 \text { Agustus } \\
2020\end{array}$ & Evaluasi Kegiatan & Luring & Tim \\
\hline 10 & $\begin{array}{ll}29 & \text { Agustus } \\
2020 & \end{array}$ & $\begin{array}{l}\text { Kegiatan publikasi artikel di Jurnal } \\
\text { Saintifik }\end{array}$ & Luring & Tim \\
\hline
\end{tabular}

\section{Hasil dan Pembahasan}

Setelah proses pelatihan dan pendampingan penulisan artikel ilmiah dilakukan selama sembilan kali pertemuan, maka didapatkan hasil berupa artikel ilmiah dari guru MTs Muhammadiyah 1 Malang. Adapun artikel tersebut masih perlu proses review untuk menghasilkan kualitas artikel yang layak untuk diterbitkan di Jurnal SAINTIFIK Volume 7 Nomor 2 tahun 2020, milik Majelis Dikdasmen Pimpinan Daerah Muhammadiyah (PDM) Kabupaten Malang. Hasil yang lebih lengkap kegiatan pelatihan dan pendampingan penulisan artikel ilmiah diulas berikut ini.

\section{A. Hasil}

\section{(1) Sharing Permasalahan Penulisan Artikel melalui Kepala Sekolah dan Guru}

Pertemuan pertama pelaksanaan kegiatan pelatihan dan pendampingan penulisan artikel ilmiah di MTs Muhammadiyah 1 Malang dilakukan pada tanggal 9 Mei 2020. Pada pertemuan pertama tersebut, sesuai dengan judul besar subbab ini, yaitu sharing/berbagi permasalahan mengenai penulisan artikel ilmiah melalui kepala sekolah dan guru. Dalam kegiatan ini dihadiri oleh Kepala Sekolah dan 15 guru MTs Muhammadiyah 1 Malang. Kegiatan diawali dengan pembuka dan pengantar yang disampaikan oleh Kepala Sekolah. Selain itu, Kepala Sekolah juga berharap setiap guru yang mengikuti kegiatan pelatihan dan pendampingan penulisan artikel ilmiah sampai akhir dan menghasilkan artikel sesuai dengan yang ditargetkan oleh tim. 


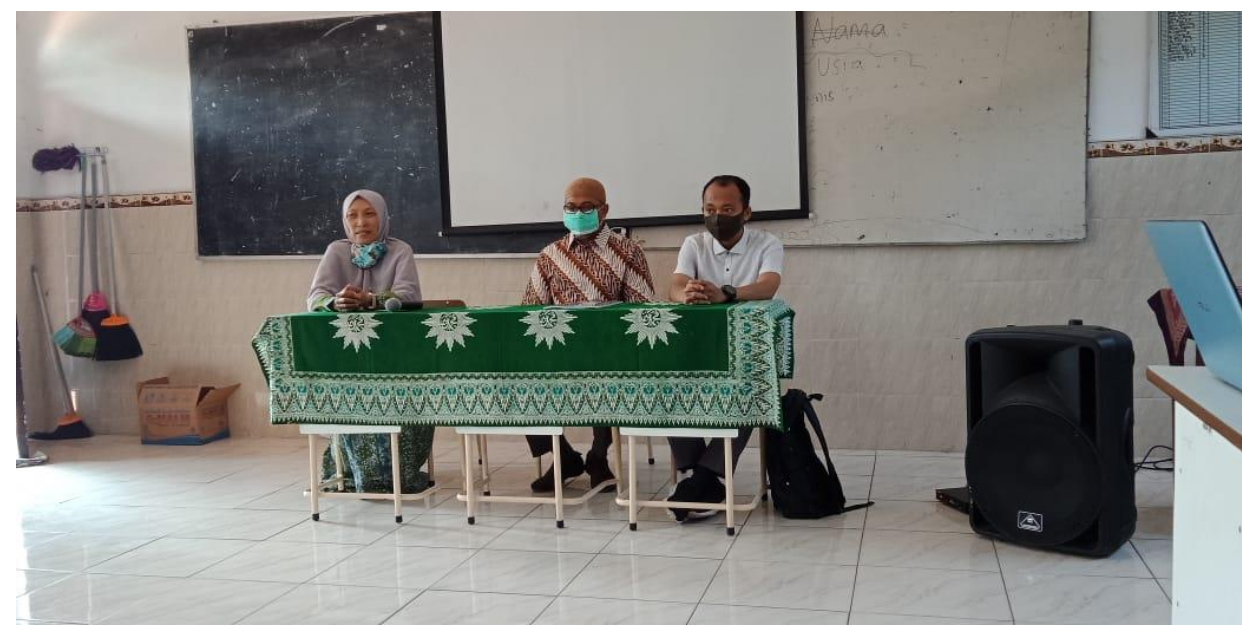

Gambar 1. Kepala Sekolah Membuka dan Memberi Sambutan Kegiatan Pelatihan dan Pendampingan Penulisan Artikel Ilmiah.

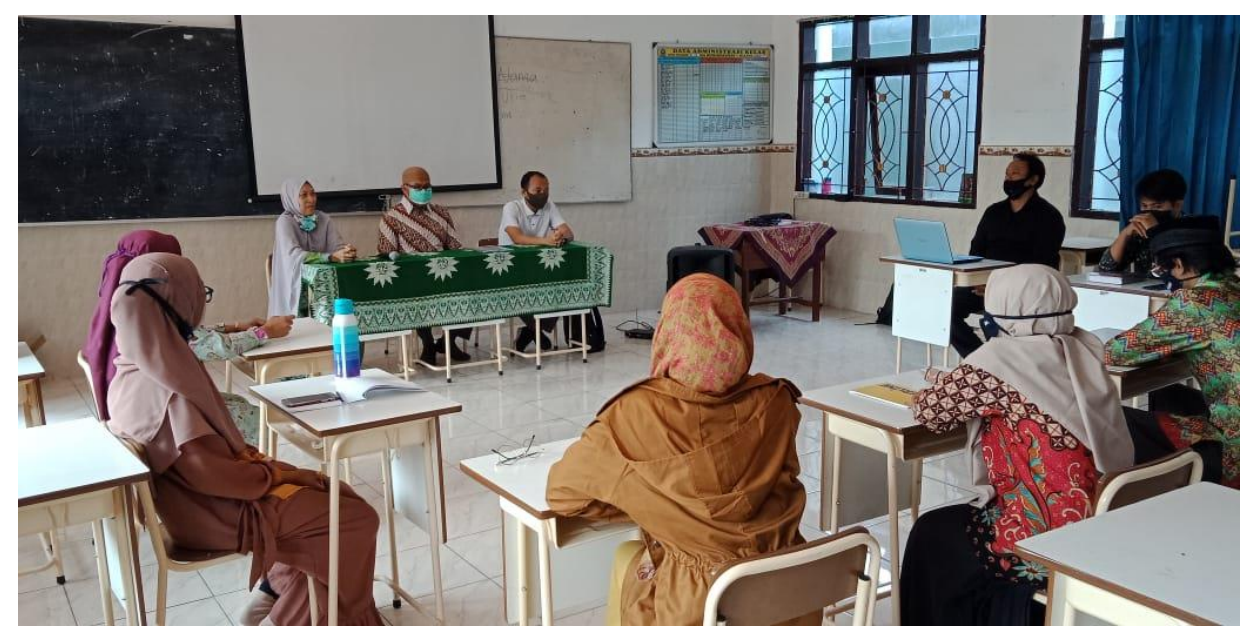

Gambar 2. Guru MTs Muhammadiyah 1 Malang mendengarkan dan mengikuti arahan dari Kepala Sekolah dan Pemateri Kegiatan Pelatihan dan Pendampingan Penulisan Artikel Ilmiah.

\section{(2) Ekspositori Konsep Ide Awal Guru MTs Muhammadiyah 1 Malang}

Pertemuan kedua dilakukan pada tanggal 23 Mei 2020. Dalam kegiatan ini peserta diminta untuk merealisasikan ide awal yang semula menjadi pembicaraan dalam kegiatan sharing/berbagi permasalahan bersama Kepala Sekolah dan guru MTs Muhammadiyah 1 Malang. Kemudian ide tersebut ditindaklanjuti menjadi sebuah konsep awal dalam penulisan artikel ilmiah. Dalam kegiatan ini guru banyak melakukan diskusi dengan pemateri, karena banyak hal baru yang didapati oleh guru. Hal ini menjadikan guru sangat bersemangat untuk segera merealisasikan ide menjadi tulisan dalam bentuk artikel ilmiah. adapun hasil ekspositori konsep sebagaimana tabel berikut.

Tabel 2. Judul Artikel Ilmiah Guru MTs Muhammadiyah 1 Malang

\begin{tabular}{cl}
\hline No & \multicolumn{1}{c}{ Judul } \\
\hline 1 & Pengembangan Model Pembelajaran Tematik Berbasis Permainan Tradisional \\
\hline 2 & $\begin{array}{l}\text { Analisis Kelimpahan dan Keanekaragaman Lumut Kerak sebagai Kualitas Udara di } \\
\text { Wilayah Kota Malang }\end{array}$ \\
\hline 3 & $\begin{array}{l}\text { Strategi Program Peningkatan Keterampilan Literasi pada Sekolah Unggul di Kota } \\
\text { Malang }\end{array}$ \\
\hline
\end{tabular}




\begin{tabular}{|c|c|}
\hline 4 & $\begin{array}{l}\text { Dua Sisi Mata Uang Pembelajaran Jarak Jauh (PJJ) Pendidikan Pancasila dan } \\
\text { Kewarganegaraan (PPKn) Berdasarkan Kurikulum Darurat Covid-19 }\end{array}$ \\
\hline 5 & $\begin{array}{l}\text { Pengembangan Ekstrakulikuler Sepak Bola Berbasis Manajemen di } \\
\text { MTs } 1 \text { Muhammadiyah } 1 \text { Malang }\end{array}$ \\
\hline 6 & $\begin{array}{l}\text { Penggunaan Media Audio Visual dalam Pembelajaran Menulis Teks Berita pada } \\
\text { Kelas VIII }\end{array}$ \\
\hline 7 & $\begin{array}{l}\text { Meningkatkan Keterampilan Bercerita pada Siswa Kelas VII MTs } 1 \text { Muhammadiyah } \\
1 \text { Malang dengan Menggunakan Media Cincin Tokoh }\end{array}$ \\
\hline 8 & Penyelesaian Masalah Matematika pada Soal Cerita Pecahan dengan Teknik Polya \\
\hline 9 & $\begin{array}{l}\text { Penerapan Pembelajaran Menulis Pantun dengan Menggunakan Metode Menulis Isi } \\
\text { pada Siswa Kelas VIIa MTs Muhammadiyah } 1 \text { Malang }\end{array}$ \\
\hline 10 & Penerapan Pembelajaran Tematik di MTs 1 Muhammadiyah 1 Malang \\
\hline 11 & $\begin{array}{l}\text { Model Penanaman Nilai-Nilai Religius dalam Upaya Mengembangkan } \\
\text { Sikap Spiritual }\end{array}$ \\
\hline
\end{tabular}

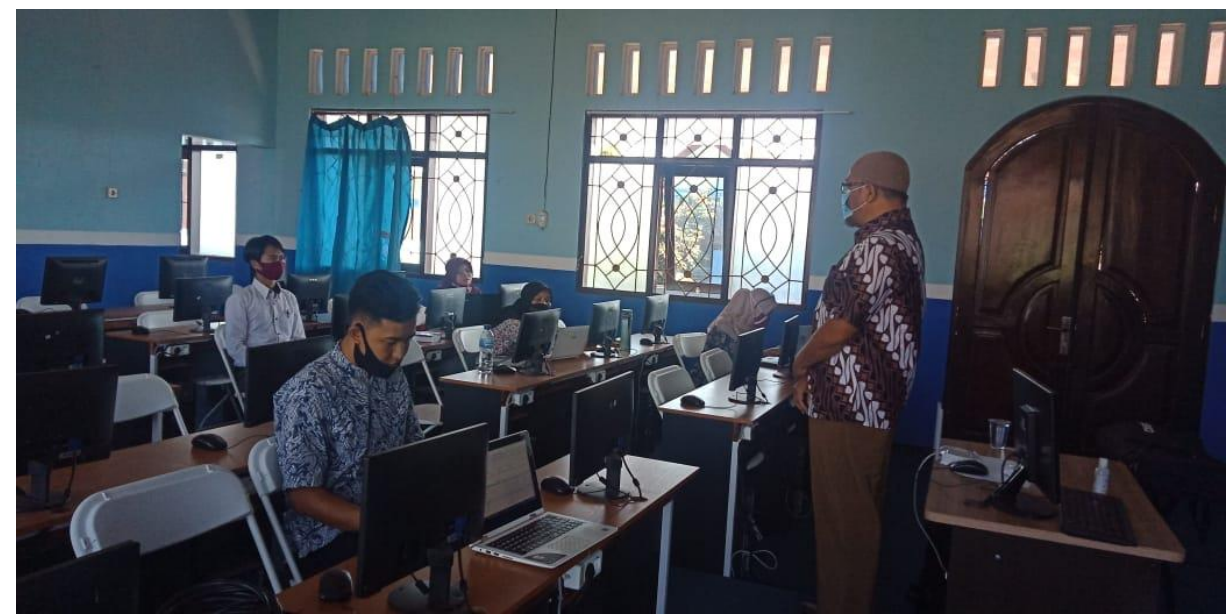

Gambar 3. Guru MTs Muhammadiyah 1 Malang melakukan Ekspositori Konsep Ide Awal Guru dalam Kegiatan Pelatihan dan Pendampingan Penulisan Artikel Ilmiah.

\section{(3) Pelatihan Penulisan Artikel}

Pertemuan ketiga sampai kelima dilaksanakan pada tanggal 6 Juni 2020, 20 Juni 2020, dan 4 Juli 2020. Tiga pertemuan ini merupakan proses pelatihan penulisan artikel ilmiah bagi guru MTs Muhammadiyah 1 Malang. Dalam pertemuan ini guru diajari mengenai mengenali pola artikel hasil pemikiran/kajian dan hasil penelitian. Kedua jenis artikel tersebut memiliki pola yang cukup berbeda, pada artikel hasil pemikiran, memiliki struktur (a) pendahuluan, (b) pembahasan, (c) penutup, dan (d) daftar pustaka, sedangkan artikel hasil penelitian memiliki struktur (a) pendahuluan, (b) metode, (c) hasil dan pembahasan, (d) kesimpulan, dan (e) daftar pustaka. Pelatihan tentang pola dan struktur artikel hasil pemikiran/kajian dan artikel hasil penelitian menjadi salah satu bagian yang sangat penting, karena menjadi tujuan akhir yang akan dicapai dalam kegiatan pengabdian ini. Pelatihan penulisan artikel yang disampikan oleh pemateri sebagaimana Gambar 4. 


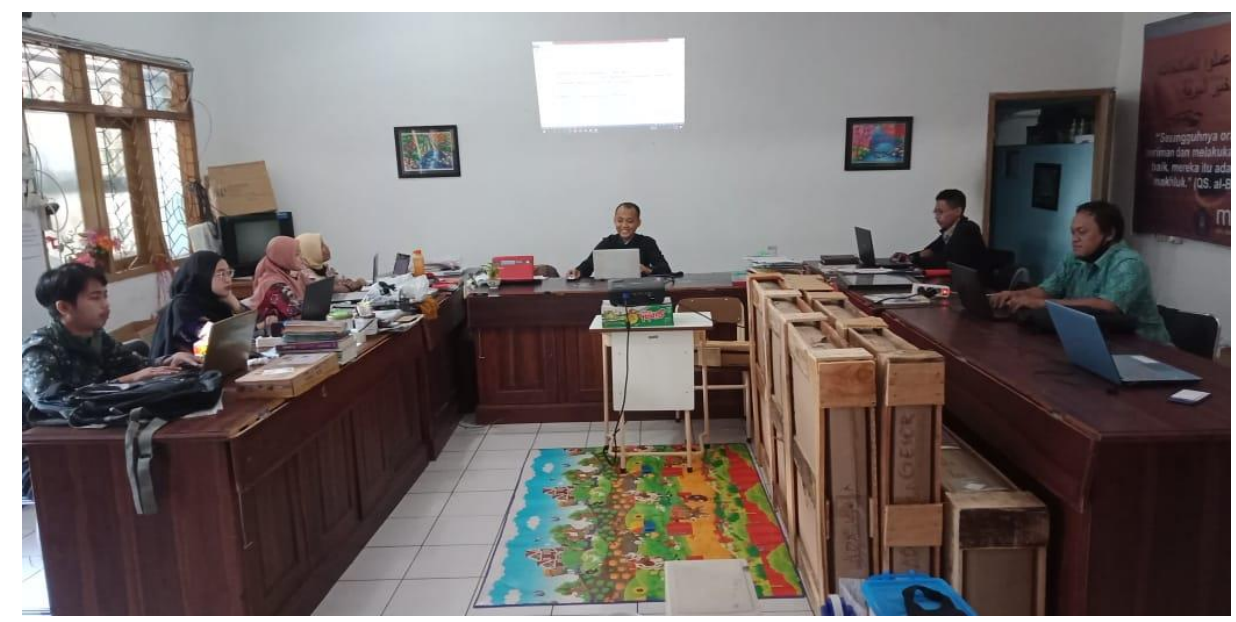

Gambar 4. Arif Setiawan, M.Pd menyampikan paparan mengenai bagian kesimpulan dan daftar pustaka pada Guru MTs Muhammadiyah 1 Malang dalam Kegiatan Pelatihan dan Pendampingan Penulisan Artikel Ilmiah.

\section{(4) Pendampingan Penulisan Artikel}

Kegiatan pendampingan dilakukan sebanyak tiga kali pertemuan yaitu pada tanggal 11 Juli 2020, 18 Juli 2020, dan 25 Juli 2020. Kegiatan pendampingan yang dilakukan, merupakan salah satu langkah untuk mengantisipasi kesulitan-kesulitan yang dialami oleh para peserta. Pada kegiatan pendampingan, diawali dengan pengenalan gaya selingkung Jurnal SAINTIFIK yang menjadi media publikasi dalam kegiatan ini. Dalam praktiknya, kegiatan pendampingan dilakukan untuk mengantarkan peserta mampu mengembangkan ide menjadi tulisan. Proses tersebut tentunya tidak berjalan dengan mudah, karena setiap instruktur harus mampu memberikan contoh kalimat atau wacana yang memiliki kohesi dan koherensi. Kegiatan ini dilakukan untuk memancing ide dan gagasan dari peserta dalam menulis artikel ilmiah.

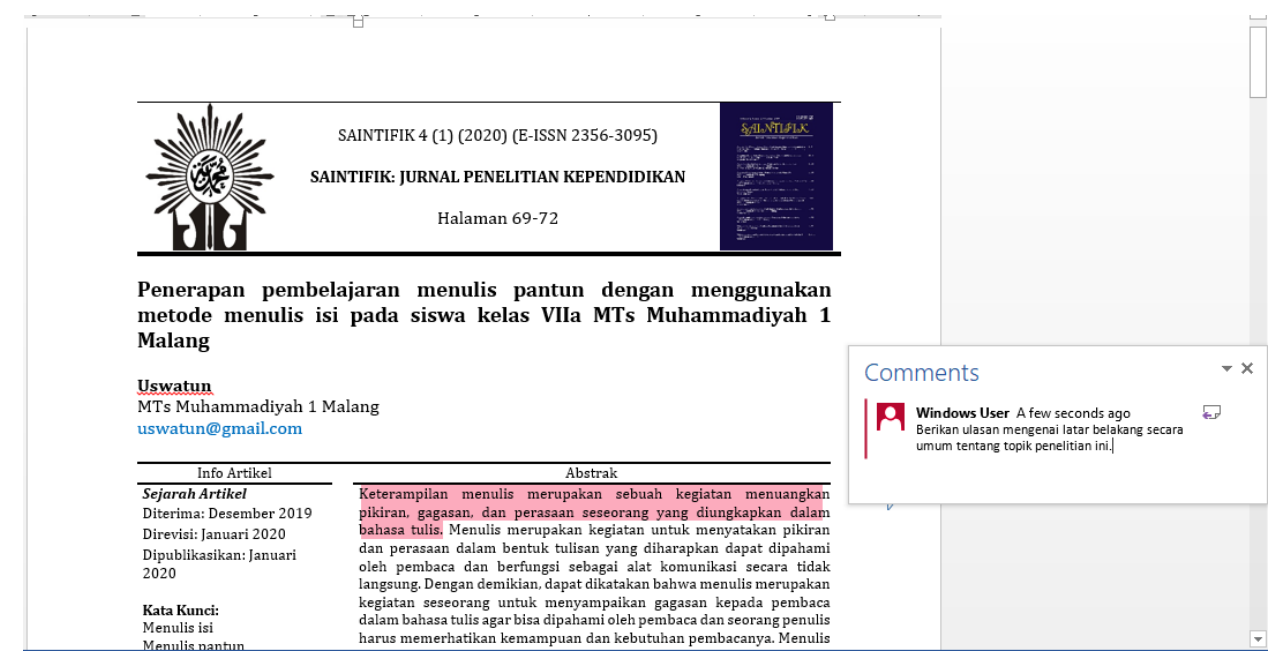

Gambar 5. Masukan yang disampaikan oleh salah satu tim pendamping terhadap abstrak yang dihasilkan oleh peserta. 


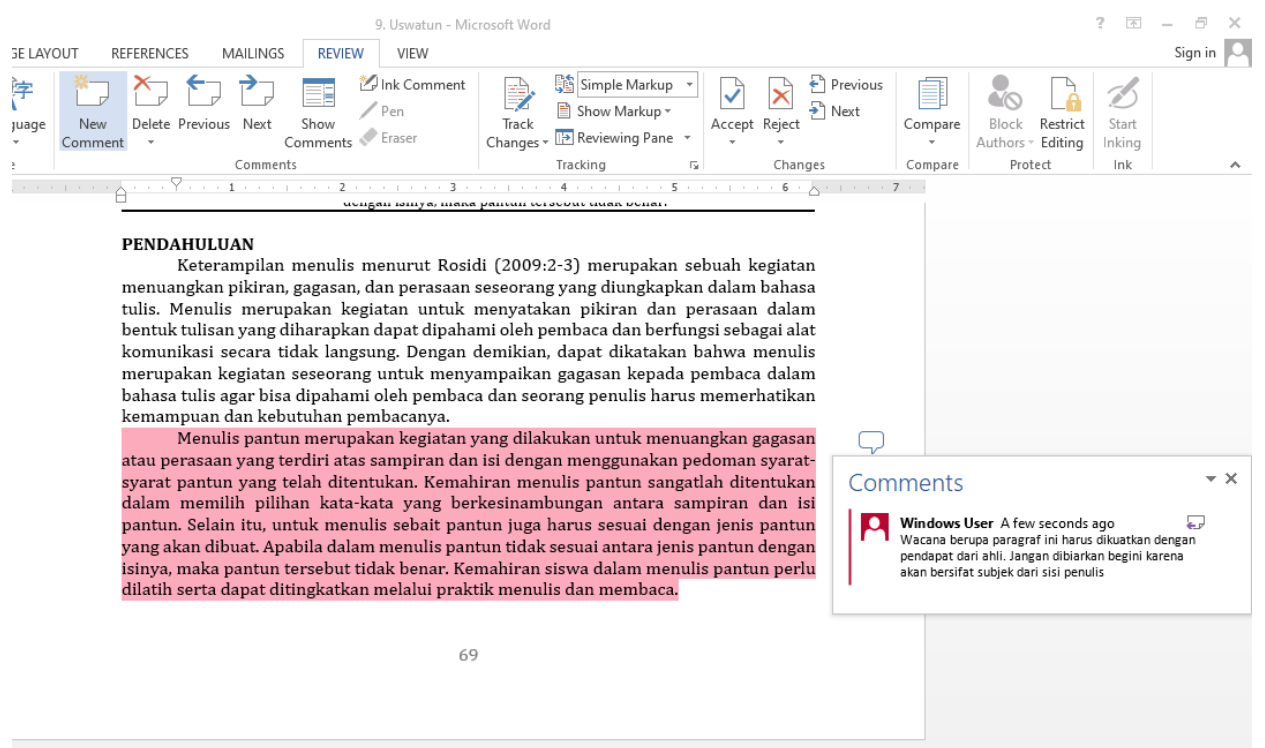

Gambar 6. Masukan yang disampaikan oleh salah satu tim pendamping terhadap pendahuluan yang dihasilkan oleh peserta.

\section{(5) Evaluasi Kegiatan}

Keberhasilan kegiatan pelatihan dan pendampingan penulisan artikel di MTs Muhammadiyah 1 Malang dapat dilihat dari produk yang dihasilkan. Produk yang dihasilkan dalam kegiatan ini adalah artikel ilmiah dalam bentuk artikel hasil pemikiran/kajian dan atau artikel hasil penelitian. Berdasarkan Gambar 7 proses evaluasi dilakukan oleh tim terhadap pelaksanaan kegiatan pelatihan dan pendampingan penulisan artikel ilmiah.

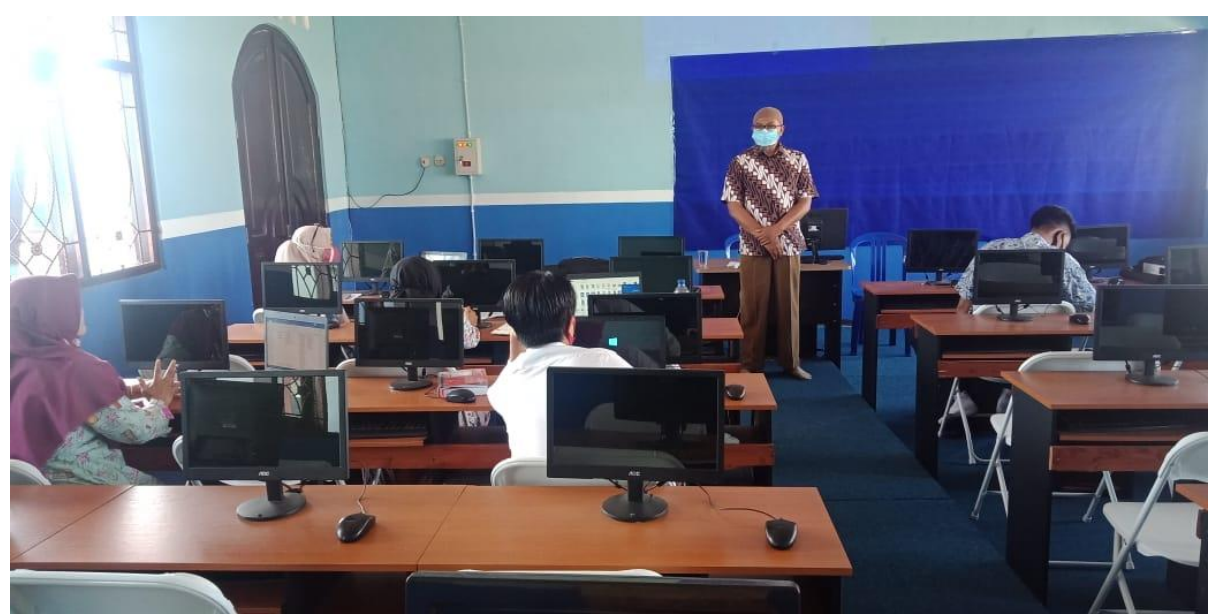

Gambar 7. Drs. Gigit Mujianto, M.Si melakukan evaluasi terhadap pelaksanaan kegiatan Pelatihan dan Pendampingan Penulisan Artikel Ilmiah.

\section{(6) Kegiatan Publikasi Artikel di Jurnal SAINTIFIK}

Langkah akhir dari kegiatan pelatihan dan pendampingan penulisan artikel ilmiah di MTs Muhammadiyah 1 Malang adalah penerbitan artikel ilmiah ke Jurnal SAINTIFIK Volume 7 Nomor 2 tahun 202, milik Majelis Dikdasmen Kabupetan Malang. Berdasarkan 14 artikel yang sudah dinyatakan selesai, maka tim melakukan seleksi dan terpilih 11 artikel ilmiah yang siap dipublikasikan di Jurnal SAINTIFIK. 


\section{B. Pembahasan}

\section{(1) Sharing Permasalahan Penulisan Artikel melalui Kepala Sekolah dan Guru}

Kegiatan sharing/berbagi permasalahan dengan Kepala Sekolah dan guru MTs Muhammadiyah 1 Malang dihadiri oleh 15 guru yang siap menjadi peserta kegiatan pelatihan dan pendampingan penulisan artikel ilmiah. Dalam kegiatan ini respons guru sangat luar biasa, di mana sebanyak 13 guru telah memiliki konsep awal tentang apa yang akan dibahas dalam menulis artikel ilmiah, sedangkan 2 orang guru masih mengalami kebingungan dalam menentukan konsep awal yang akan digunakan dalam proses penulisan artikel ilmiah, hal ini dapat dibuktikan pada Gambar 8.

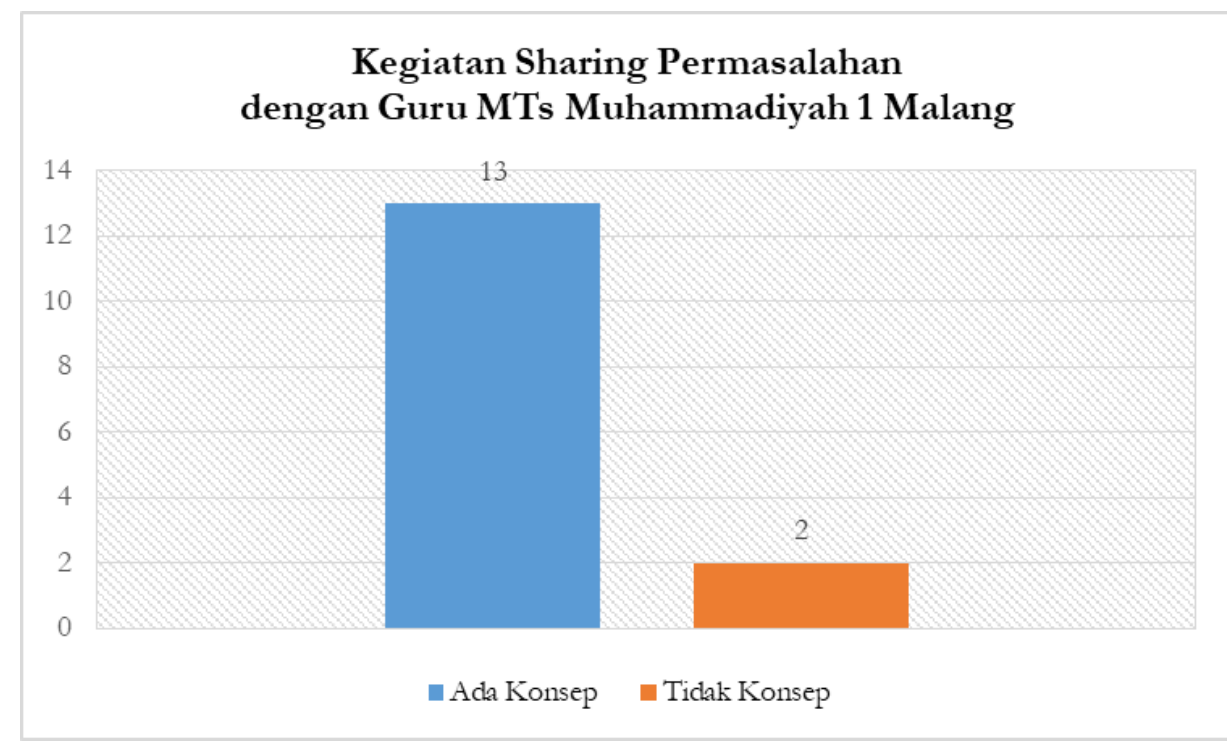

Gambar 8. Grafik Kegiatan Sharing Permasalahan Pembelajaran bersama Kepala Sekolah serta Guru di MTs Muhammadiyah 1 Malang

Dalam kegiatan sharing/berbagi permasalahan dengan Kepala Sekolah dan guru MTs Muhammadiyah 1 Malang, guru sangat tertarik banyak menanyakan bagaimana cara efektif dan dalam proses penulisan artikel ilmiah. Selain itu, ide-ide yang sebelumnya hanya dalam bentuk abstrak, ternyata meluncur dengan begitu saja. Konsep awal dan ide-ide yang telah dimiliki oleh guru MTs Muhammadiyah 1 Malang kemudian diarahkan kepada sebuah permasalahan yang dapat diangkat menjadi artikel ilmiah. Kondisi ini sejalan dengan pengabdian sebelumnya yang menyatakan bahwa dalam kegiatan awal pelatihan, guru harus diberikan penguatan terlebih dahulu agar memantapkan ide yang sudah dimiliki, yang dilanjutkan dengan proses penulisan artikel ilmiah (Ilfiandra et al., 2016). Pemberian penguatan kepada guru bertujuan untuk menumbuhkan rasa percaya diri pada guru (Rahmatullah dan Inanna, 2019), sehingga guru memiliki motivasi dan semangat (Permana dkk, 2017) dalam mengikuti kegiatan pelatihan dan pendampingan penulisan artikel ilmiah. Kegiatan tersebut ditutup dengan arahan dan masukan dari tim untuk menjadikan ide-ide sebagai konsep awal artikel yang akan ditulis.

\section{(2) Ekspositori Konsep Ide Awal Guru MTs Muhammadiyah 1 Malang}

Kegiatan ekspositori konsep diawali dengan penjelasan secara garis besar mengenai konsep artikel ilmiah yang akan ditulis guru. Pada kegiatan ini, proses diskusi dan tanya jawab menjadi menu utama yang sangat jelas terlihat dalam pelaksanaannya. Kondisi tersebut dapat 
dilihat pada Gambar 9 yang menunjukkan grafik tanya jawab antara pemateri dengan guru MTs Muhammadiyah 1 Malang.

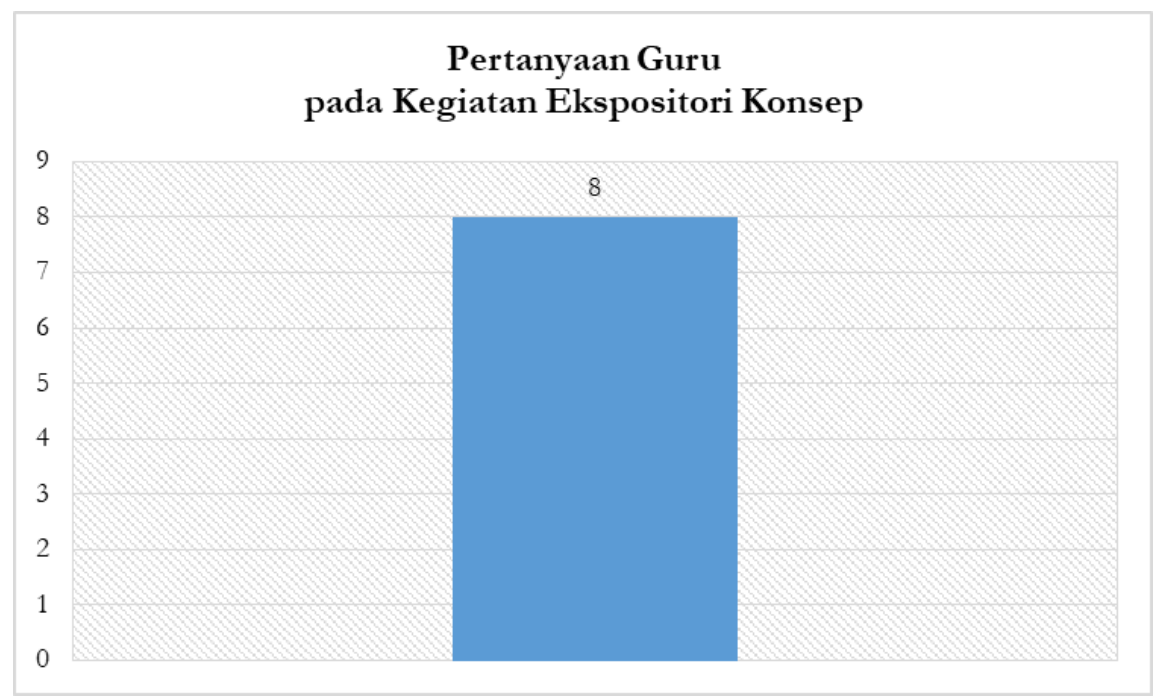

Gambar 9. Sesi Tanya Jawab dalam Kegiatan Ekspositori Konsep

Berdasarkan Gambar 9, menunjukkan bahwa kegiatan ekspositori konsep ide, diskusi, dan tanya jawab menjadi sangat menarik dan berjalan mengalir dengan banyak ide yang muncul dari guru. Hal ini dibuktikan dengan adanya 8 pertanyaan secara bergiliran yang diajukan oleh guru MTs Muhammadiyah 1 Malang. Dalam Kegiatan tanya jawab dan diskusi yang dilakukan, ternyata menjadi sebuah wadah untuk mengapresiasi semua aspirasi dan keingintahuan guru akan sebuah informasi (Nalole, 2010), utamanya dalam menulis artikel ilmiah. Temuan ini semakin menguatkan bahwa kemampuan bertanya menjadi satu kompetensi yang wajib oleh siapa pun untuk menggali informasi yang belum diketahui sebelumnya (Cahyani dkk, 2016). Oleh karena itu, dapat dikatakan bahwa kemampuan bertanya sangat berguna untuk mengeksplorasi informasi yang masih belum jelas dari siapa pun (Cahyani dkk, 2016), serta sangat bermanfaat untuk membina hubungan yang baik dengan sesama (Nalole, 2010).

Proses diskusi dan tanya jawab yang telah dilakukan dengan guru MTs Muhammadiyah 1 Malang, akhirnya disepakati 6 judul yang akan ditindaklanjuti menjadi artikel ilmiah seperti pada Gambar 10.

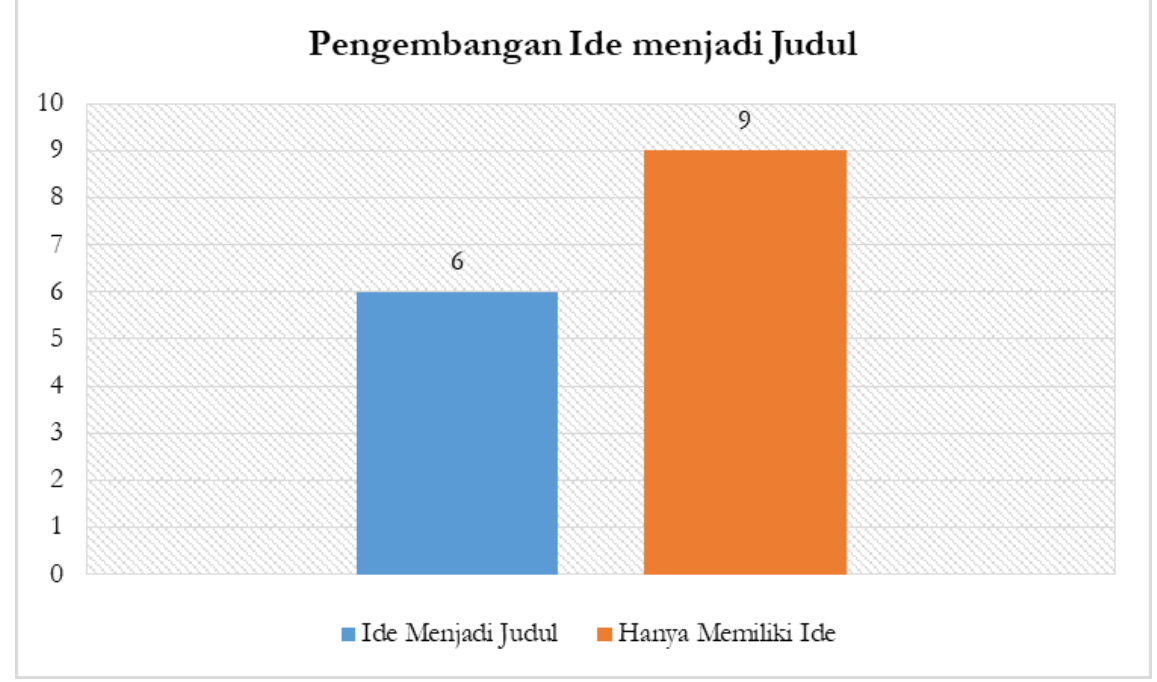

Gambar 10. Perwujudan Ide Menjadi Judul Artikel Ilmiah 
Keenam judul yang telah dihasilkan, disusun berdasarkan masing-masing bidang keilmuan, keahlian, dan kegiatan pembelajaran yang telah dilakukan oleh guru. Hal ini menjadi salah satu keuntungan tersendiri bagi guru, karena pengembangan kerangka artikel ilmiah berdasarkan proses yang sudah dilakukan setiap harinya, sedangkan guru yang hanya memiliki ide sebanyak 9 orang.

\section{(3) Pelatihan Penulisan Artikel}

Pelatihan terkait dengan pola artikel hasil pemikiran/kajian dan artikel hasil penelitian menjadi salah satu bagian yang sangat penting. Hal ini dikarenakan hasil akhir dari pengabdian ini berupa artikel hasil pemikiran/artikel hasil penelitian. Dalam kegiatan pelatihan ini materi disampaikan oleh tiga pemateri, (a) materi pertama terkait dengan judul, pendahuluan, disampaikan oleh Drs. Gigit Mujianto, M.Si, (b) materi terkait dengan metode serta hasil dan pembahasan disampaikan oleh Mussafak, M.Pd, dan (c) materi mengenai kesimpulan/penutup, dan daftar pustaka disampaikan oleh Arif Setiawan, M.Pd. Pemahaman yang baik tentang struktur atau pola artikel hasil pemikiran/artikel hasil penelitian diharapkan dapat memudahkan guru untuk merealisasikan ide menjadi artikel ilmiah. Hal ini sejalan dengan pengabdian sebelumnya yang telah dilakukan oleh (Ilfiandra dkk, 2016), bahwa dalam kegiatan pelatihan penulisan artikel ilmiah, peserta perlu memahami dengan baik terhadap struktur artikel yang akan ditulis. Pelaksanaan kegiatan pelatihan ini mendorong antusiasme guru untuk berpartisipasi dengan baik, kondisi tersebut ditunjukkan pada Gambar 11.

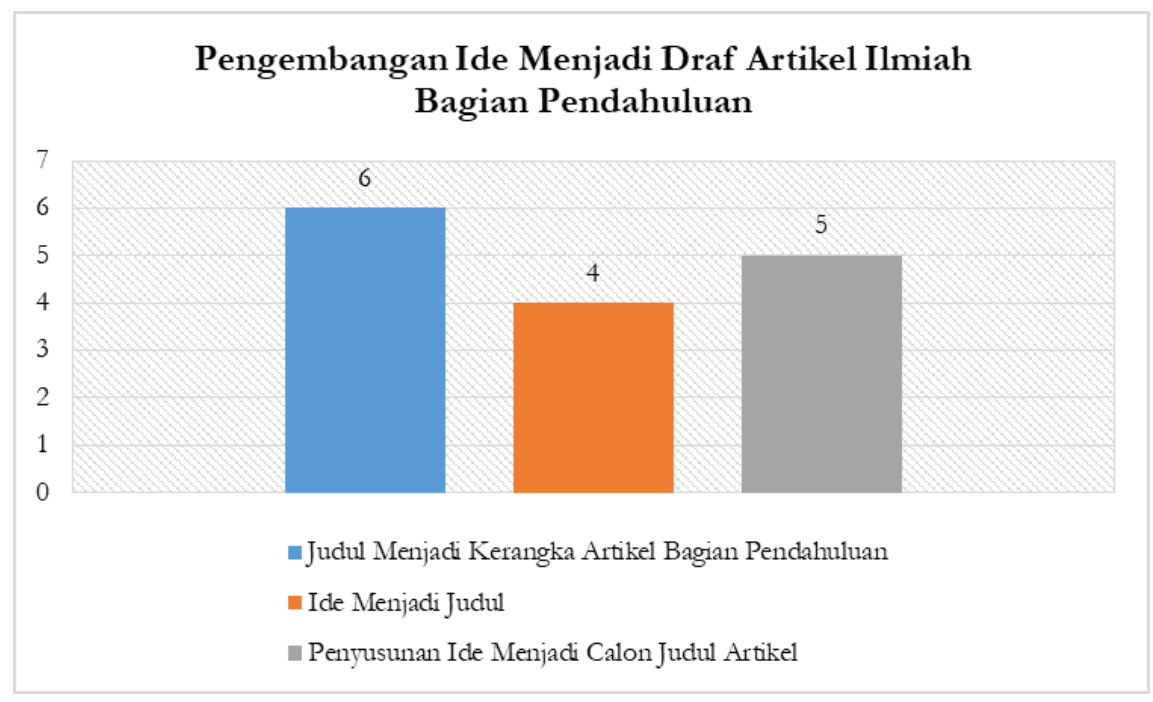

Gambar 11. Grafik Pengembangan Ide Menjadi Judul Artikel Ilmiah

Berdasarkan Gambar 11, terdapat 6 guru telah mampu mengembangkan judul menjadi kerangka artikel bagian pendahuluan, kemudian terdapat 4 guru yang telah menyusun ide menjadi judul, serta masih terdapat 5 guru yang baru menyusun ide menjadi calon judul artikel. Hal ini dikarenakan kegiatan penulisan artikel ilmiah dianggap hal yang masih baru bagi para guru.

\section{(4) Pendampingan Penulisan Artikel}

Tingkat ketercapaian dalam kegiatan ini menjadi bagian yang sangat penting dalam pelaksanaan kegiatan pelatihan dan pendampingan penulisan artikel ilmiah, karena tingkat kemandirian guru dalam mewujudkan ide menjadi artikel ilmiah. Pelaksanaan kegiatan pendampingan penulisan artikel ilmiah secara lengkap dapat dilihat pada Gambar 12. 


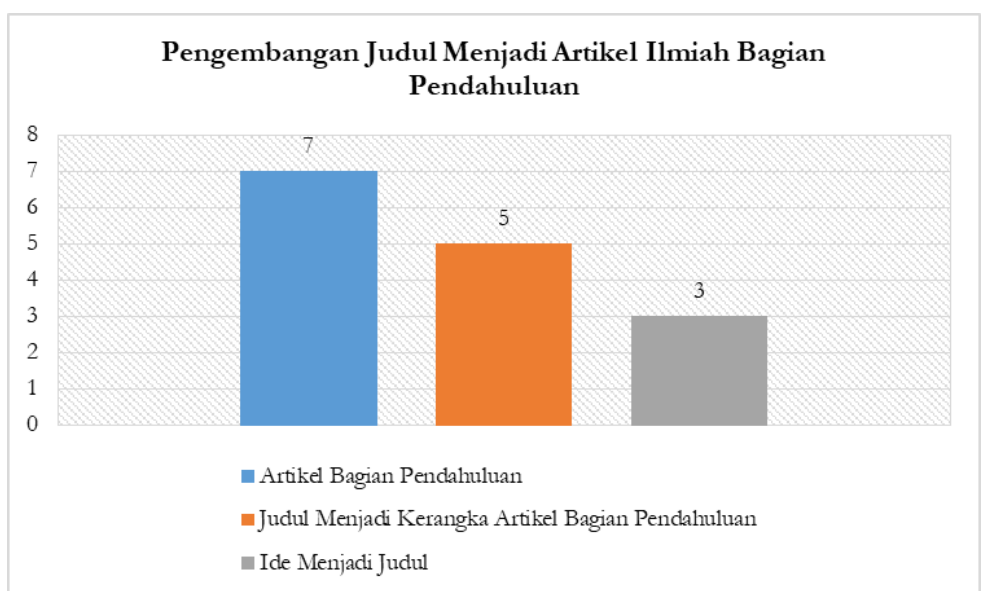

Gambar 12. Grafik Pengembangan Judul Menjadi Artikel Ilmiah Bagian Pendahuluan

Berdasarkan Gambar 12, didapatkan infromasi bahwa proses pendampingan yang dilakukan terhadap 15 guru MTs Muhammadiyah 1 Malang berjalan sangat baik. Hal ini dibuktikan dengan sebanyak 7 guru telah menulis artikel ilmiah bagian pendahuluan, 5 guru telah menyusun judul menjadi kerangka artikel ilmiah bagian pendahuluan, dan sebanyak 3 guru telah menyusun ide menjadi judul artikel ilmiah. Berdasarkan Gambar 12, dapat disimpulkan bahwa terdapat kemajuan yang sangat signifikan dari pada pertemuan ketiga sampai kelima dalam kegiatan pelatihan dan pendampingan penulisan artikel ilmiah.

Pendampingan penulisan artikel ilmiah selanjutnya dilaksanakan pada tanggal 18 Juli 2020. Pada pertemuan ketujuh ini, agenda yang akan dibahas adalah proses penulisan ide menjadi artikel bagian pembahasan/metode serta penutup/hasil dan pembahasan. Berdasarkan Gambar 13 didapatkan infromasi mengenai kemajuan guru dalam mengikuti kegiatan pendampingan penulisan artikel. Hal ini dibuktikan dengan sebanyak 9 guru telah menulis artikel bagian pembahasan/metode serta penutup/hasil dan pembahasan, sebanyak 3 guru telah menulis artikel bagian pendahuluan, serta sebanyak 3 guru yang telah menyusun judul menjadi kerangka artikel bagian pendahuluan.

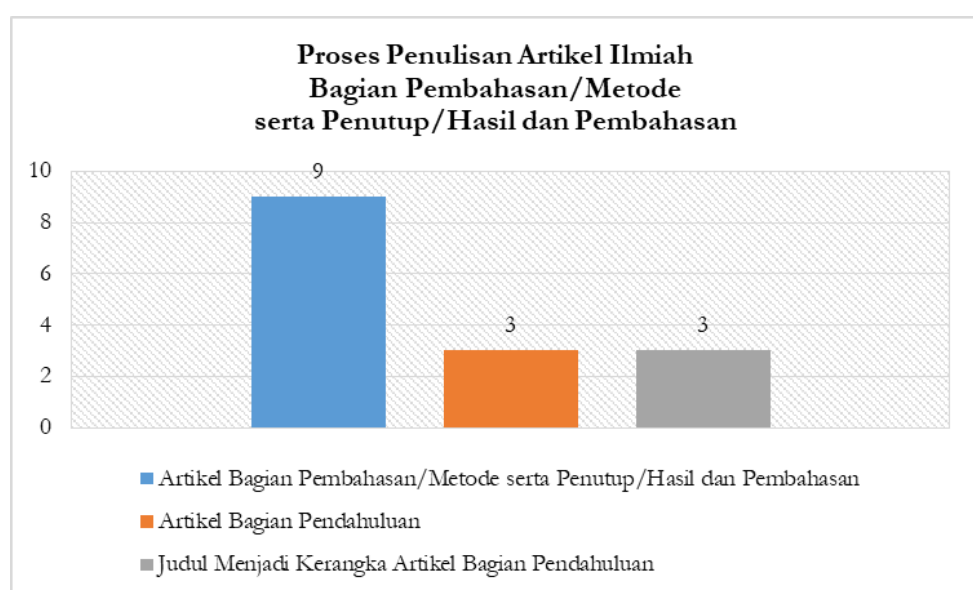

Gambar 13. Grafik Proses Penulisan Artikel Ilmiah Bagian Pembahasan/Metode serta Penutup/Hasil dan Pembahasan

Pendampingan penulisan artikel ilmiah selanjutnya dilaksanakan pada tanggal 25 Juli 2020. Pada pertemuan kedelapan ini, agenda pendampingan adalah proses penulisan ide menjadi artikel bagian kesimpulan, dan dilanjutkan dengan daftar pustaka. Berdasarkan 
Gambar 14 didapatkan data mengenai kemajuan guru dalam mengikuti kegiatan pendampingan penulisan artikel. Hal ini dibuktikan dengan sebanyak 11 guru telah menyelesaikan penulisan artikel ilmiah bagian kesimpulan dan daftar pustaka, sebanyak 3 guru telah menyelesaikan artikel bagian pembahasan/metode serta penutup/hasil dan pembahasan, serta 1 guru yang telah menyusun artikel bagian pendahuluan.

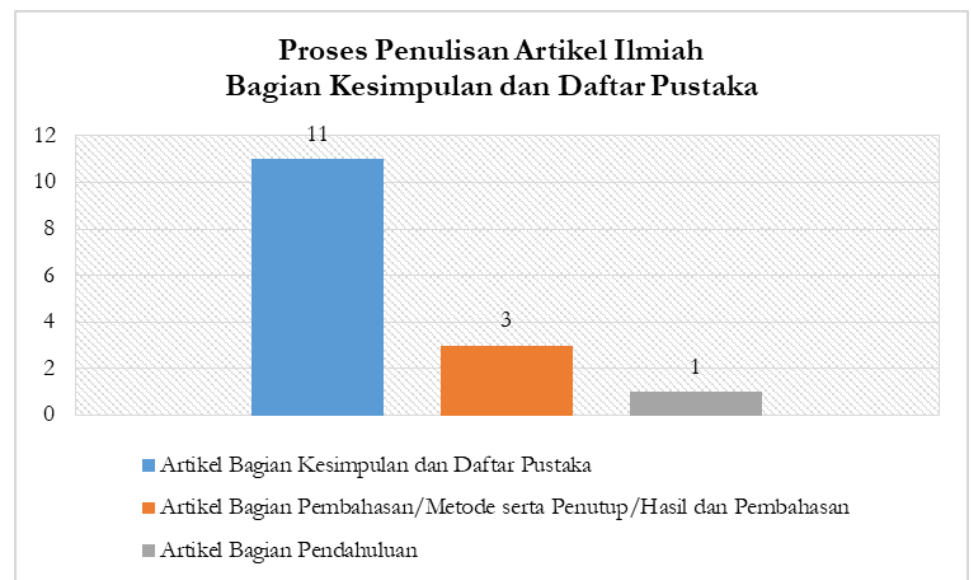

Gambar 14. Grafik Proses Penulisan Artikel Ilmiah Bagian Kesimpulan dan Daftar Pustaka

Secara umum pelaksanaan proses pendampingan penulisan artikel ilmiah, ternyata banyak terjadi proses transformasi ilmu pengetahuan mengenai penulisan artikel ilmiah bagi guru MTs Muhammadiyah 1 Malang. Transformasi yang terjadi, telah memberikan rasa percaya diri yang lebih kepada guru, sehingga proses perwujudan ide menjadi artikel ilmiah menjadi lebih menyenangkan dan tidak menjadi beban. Kondisi tersebut semakin menunjukkan bahwa kemampuan dalam memahami bagian isi akan menambah rasa percaya diri guru untuk menulis, temuan ini semakin menguatkan hasil pengabdian sebelumnya yang dilakukan oleh (Aisyah dan Mahanani, 2017)

\section{(5) Evaluasi Kegiatan}

Keberhasilan kegiatan pelatihan dan pendampingan penulisan artikel di MTs Muhammadiyah 1 Malang dapat dilihat dari produk yang dihasilkan. Produk yang dihasilkan adalah artikel ilmiah dalam bentuk artikel hasil pemikiran/kajian dan atau artikel hasil penelitian. Adapun detail dari kegiatan evaluasi pelatihan dan pendampingan penulisan artikel ilmiah dapat dilihat pada Gambar 15.

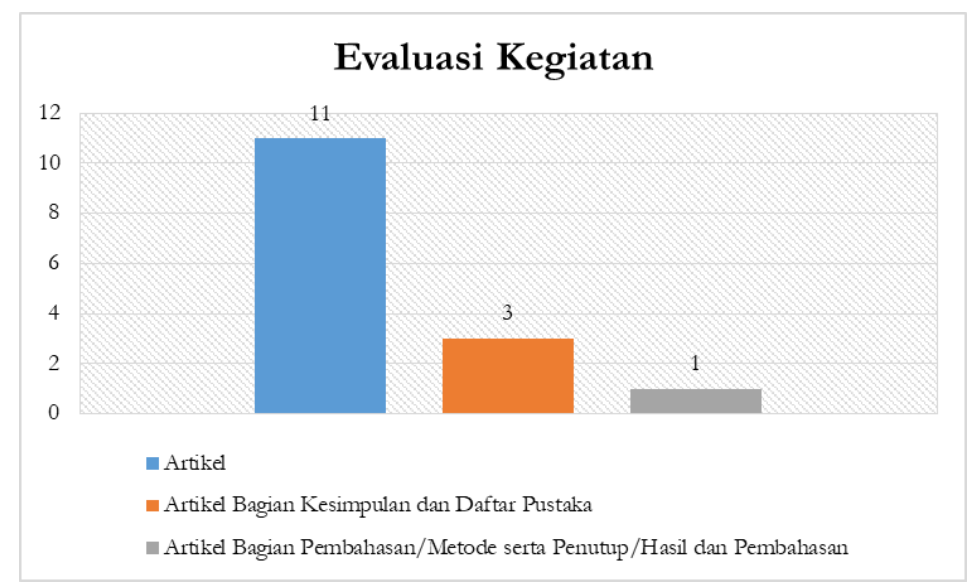

Gambar 15. Grafik Evaluasi Kegiatan Proses Penulisan Artikel Ilmiah 
Gambar 15 menunjukkan data bahwa sebanyak 11 guru telah menyelesaikan tagihan kegiatan dalam bentuk artikel ilmiah. Selain itu, masih terdapat 3 guru yang sudah hampir menyelesaikan tagihan artikel ilmiah, serta 1 guru yang masih pada proses penulisan artikel bagian pembahasan/metode serta penutup/hasil dan pembahasan. Berdasarkan Gambar 15, dapat disimpulkan bahwa kegiatan pelatihan dan pendampingan penulisan artikel ilmiah di MTs Muhammadiyah 1 Malang dinyatakan berhasil. Hal ini diperkuat dengan data sebanyak 11 guru telah menyelesaikan tagihan dalam bentuk artikel ilmiah. Secara umum, hasil evaluasi menunjukkan bahwa kesadaran menulis pada guru harus ditumbuhkan, sehingga menjadi sebuah kebiasaan yang mengakar erat. Hal ini akan menjadikan guru semakin profesional dalam menjalankan tugasnya sebagai salah satu agen perubahan, serta kapasitas akademiknya dapat diakui oleh khalayak (Kasiyan dkk, 2019).

\section{(6) Kegiatan Publikasi Artikel di Jurnal SAINTIFIK}

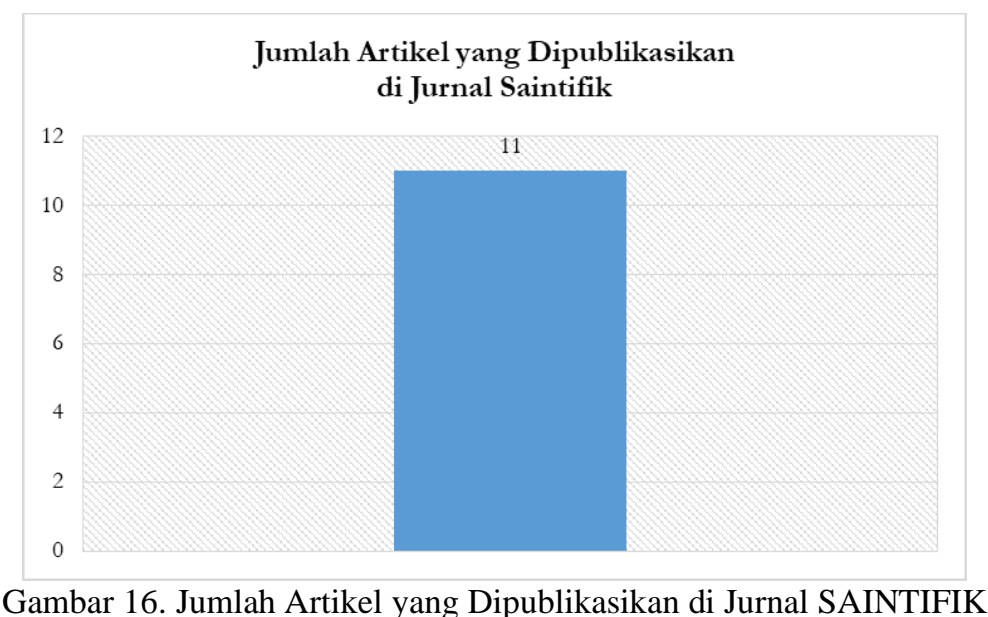

Langkah akhir dari kegiatan pelatihan dan pendampingan penulisan artikel ilmiah bagi guru MTs Muhammadiyah 1 Malang adalah penerbitan artikel ilmiah ke Jurnal SAINTIFIK Volume 7 Nomor 2, tahun 2020. Berdasarkan 14 artikel yang sudah dinyatakan selesai, maka tim melakukan seleksi dan terpilih 11 artikel ilmiah yang siap dipublikasikan di Jurnal. Hasil seleksi menunjukkan bahwa terdapat 11 naskah artikel ilmiah yang layak untuk dipublikasikan pada Jurnal SAINTIFIK Volume 7 Nomor 2 tahun 2020, milik Majelis Dikdasmen Pimpinan Daerah Muhammadiyah (PDM) Kabupaten Malang. Berdasarkan Gambar 15 dan Gambar 16, Jurnal SAINTIFIK yang diketuai oleh Prof. Ahsanul In'am, P.hD, kemudian dikelola olah Drs. Gigit Mujianto, M.Si dan Arif Setiawan, M.Pd, jadwal penerbitan sebanyak dua kali dalam satu tahun yaitu pada bulan Januari dan Juli. 


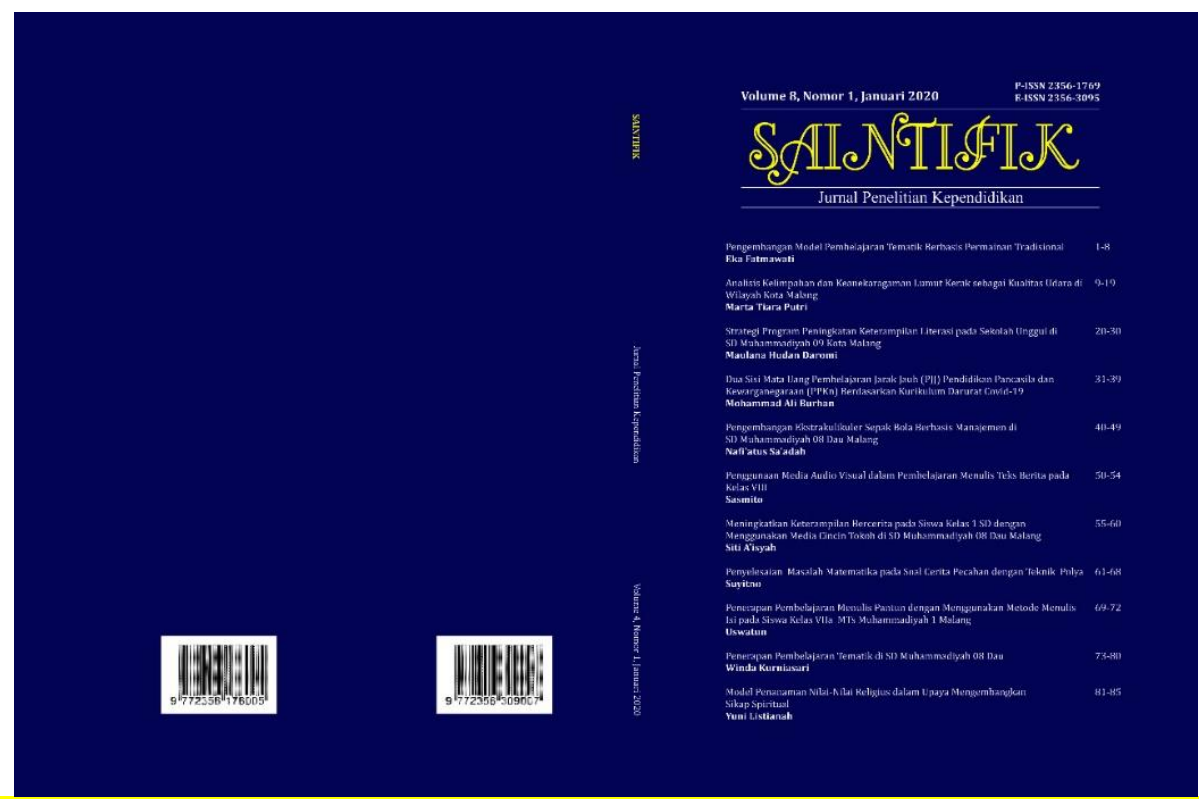

Gambar 17. Cover Jurnal SAINTIFIK

\section{Simpulan}

Kegiatan pelatihan dan pendampingan penulisan artikel ilmiah dilaksanakan di MTs Muhammadiyah 1 Malang. Kegiatan tersebut telah mampu mengantarkan guru MTs FMuhammadiyah 1 Malang untuk menulis artikel ilmiah dalam bentuk hasil pemikiran/kajian dan hasil penelitian. Dari 15 guru yang menjadi peserta, didapatkan 14 artikel yang dihasilkan dan siap untuk dipublikasikan. Dari 14 artikel ilmiah yang dihasilkan kemudian terpilih sebanyak 11 artikel ilmiah diterbitkan di Jurnal SAINTIFK, sedangkan sisanya akan direvisi berdasarkan masukan reviewer dan akan dipublikasikan pada Volume 8 Nomor 1, tahun 2020. Melalui temuan yang telah didapatkan, kegiatan pelatihan dan pendampingan penulisan artikel ilmiah di MTs Muhammadiyah 1 Malang sangat direkomendasikan. Kegiatan pelatihan dan pendampingan seperti ini perlu dilakukan lebih sering lagi agar keterampilan menulis yang dimiliki oleh guru semakin terasah, sehingga kapasitas akademik seorang guru dapat diakui oleh khalayak.

\section{Ucapan Terima Kasih}

Ucapan terima kasih disampaikan kepada Direktorat Penelitian dan Pengabdian Masyarakat (DPPM) Universitas Muhammadiyah Malang yang telah membimbing dan membiayai pengabdian ini. Kemudian kepada Ketua Program Studi Pendidikan Bahasa Indonesia FKIP UMM yang telah mendukung penuh kegiatan pengabdian ini. Terima kasih juga kepada seluruh Guru MTs Muhammadiyah 1 Malang yang telah bersedia mengikuti kegiatan pengabdian ini, sehingga kegiatan ini dapat diselesaikan dengan baik.

\section{Daftar Pustaka}

Aghittara, A. O. (2016). Peningkatan Keterampilan Menulis Cerita Fiksi Melalui Metode Eksplorasi Membaca Siswa Kelas IV. Basic education, 5(30), 28-31.

Aisyah, E. N., \& Mahanani, P. (2017). Pelatihan menulisan artikel ilmiah bagi guru sekolah 
dasar dan taman kanak-kanak kecamatan Tajinan kabupaten Malang. Abdimas Pedagogi: Jurnal Ilmiah Pengabdian Kepada Masyarakat, 1(1), 22-26. Https://doi.org/http://dx.doi.org/10.17977/um050v1i1p\%25p

Arta, K. S. (2019). Pelatihan penulisan artikel untuk publikasi di jurnal ilmiah untuk meningkatkan profesionalisme bagi guru-guru di Kecamatan Kubutambahan Kabupaten Buleleng. In Seminar Nasional Hukum dan Ilmu Sosial (Vol. 2, pp. 146159).

Cahyani, P. A. H. I., Nurjaya, I. G., \& Sriasih, S. A. P. (2016). Analisis keterampilan bertanya guru dan siswa dalam pembelajaran bahasa Indonesia di Kelas X TAV 1 SMK Negeri 3 Singaraja. Jurnal Pendidikan Bahasa Dan Sastra Indonesia Undiksha, 3(1), 1-12. Https://doi.org/http://dx.doi.org/10.23887/jjpbs.v3i1.7204

Chairunnisa, C. (2016). Pemberdayaan Guru Melalui Pelatihan Penulisan Karya Ilmiah Di Sekolah Menengah Kejuruan. Faktor: Jurnal Ilmiah Kependidikan, 3(2), 105-114. Https://doi.org/https://journal.lppmunindra.ac.id/index.php/Faktor/article/view/777

Ekosiswoyo, R. (2016). Kepemimpinan kepala sekolah yang efektif kunci pencapaian kualitas pendidikan. Jurnal Ilmu Pendidikan, 14(2), 76-82. Https://doi.org/http://dx.doi.org/10.17977/jip.v14i2.24

Ilfiandra, I., Suherman, U., Akhmad, S. N., Budiamin, A., \& Setiawati, S. (2016). Pelatihan dan pendampingan penulisan karya tulis ilmiah bagi guru SD. Jurnal Pengabdian Pada Masyarakat, 1(1), 70-81. Https://doi.org/https://doi.org/10.30653/002.201611.10

Ismail, M. I. (2010). Kinerja dan kompetensi guru dalam pembelajaran. Lentera Pendidikan : Jurnal Ilmu Tarbiyah dan Keguruan, 13(1), 44-63. Https://doi.org/10.24252/lp.2010v13n1a4

Jana, P., \& Pamungkas, B. (2018). Pelatihan penelitian tindakan kelas bagi guru SD Negeri Guwosari. Abdimas Dewantara, 1(1), 39-46. Https://doi.org/https://pdfs.semanticscholar.org/55f1/12c119fb09e409b12bae6fd8db60 c3309761.pdf

Kasiyan, K., Zuhdi, B. M., Hendri, Z., Handoko, A., \& Sitompul, M. (2019). Pelatihan penulisan karya ilmiah untuk peningkatan profesionalisme guru. JPPM (Jurnal Pengabdian Dan Pemberdayaan Masyarakat), 3(1), 47-53. Https://doi.org/10.30595/jppm.v3i1.3128

Mansyur, U., \& Akidah, I. (2018). Peningkatan kompetensi profesional guru Mts DDI Padanglampe Kabupaten Pangkep melalui pelatihan penulisan karya tulis ilmiah. JPPM (Jurnal Pengabdian Dan Pemberdayaan Masyarakat), 2(2), 273-278. Https://doi.org/10.30595/jppm.v2i2.2589

Marlena, N., Dwijayanti, R., Patrikha, F. D., \& Parjono, P. (2017). Pelatihan Penulisan Karya Tulis Ilmiah (KTI) bagi Guru SMA Swasta di Sidoarjo. Jurnal ABDI: Media Pengabdian Kepada Masyarakat, 2(2), 45-50. Https://doi.org/http://dx.doi.org/10.26740/ja.v2n2.p45-50

Martati, B., \& Setyorini, A. (2019). Pelatihan Penulisan Cerita Pendek Berbasis Multikulturalisme untuk Guru-Guru Sekolah Dasar Muhammadiyah di Surabaya. JPP IPTEK (Jurnal Pengabdian Dan Penerapan IPTEK), 3(1), 1-6. Https://doi.org/https://doi.org/10.31284/j.jpp-iptek.2019.v3i1.320

Muspawi, M. (2014). Pengembangan Model Kepemimpinan Kepala Sekolah yang Berorientasi pada Kinerja Sekolah Efektif (Studi Kepemimpinan Kepala SD No. 02/vii Pasar Sarolangun Kabupaten Sarolangun). Jurnal Penelitian Universitas Jambi: Seri Humaniora, 16(1), 19-22. Retrieved from https://www.neliti.com/id/publications/43456/pengembangan-model-kepemimpinan- 
kepala-sekolah-yang-berorientasi-pada-kinerja-se\#cite

Nalole, M. (2010). Kemampuan guru menerapkan ketrampilan bertanya pada pembelajaran matematika di kelas IV SDN No. 64 Kota Timur Kota Gorontalo. Jurnal Inovasi, 7(2), 33-43. Retrieved from http://ejurnal.ung.ac.id/index.php/JIN/article/viewFile/778/721

Permana, E. P., Mujiwati, E. S., Sahari, S., Santi, N. N., Damariswara, R., Mukmin, B. A., ... Saidah, K. (2017). Pelatihan Penulisan Karya Ilmiah Untuk Guru Sekolah Dasar Pada Anggota Gugus 1 Kecamatan Ringinrejo Kabupaten Kediri. Jurnal ABDINUS: Jurnal Pengabdian Nusantara, 1(1), 53-68. https://doi.org/https://doi.org/10.29407/ja.v1i1.11729

Rahmatullah, R., \& Inanna, I. (2019). Pelatihan Penulisan Penelitian Tindakan Kelas Bagi Guru. Jurnal Dedikasi Masyarakat, 3(1), 19-25. https://doi.org/http://dx.doi.org/10.31850/jdm.v3i1.448

Soejoto, A., Fitrayati, D., Ghofur, M. A., Prakoso, A. F., \& others. (2017). Pelatihan penulisan proposal penelitian tindakan kelas (PTK). Jurnal ABDI: Media Pengabdian Kepada Masyarakat, 2(2), 51-59. https://doi.org/http://dx.doi.org/10.26740/ja.v2n2.p51-59

Soesatyo, Y., Subroto, W. T., Sakti, N. C., Edwar, M., \& Trisnawati, N. (2017). Pelatihan Penulisan Proposal Penelitian Tindakan Kelas (PTK) Bagi Guru Ekonomi Kabupaten Sidoarjo. Jurnal Pemberdayaan Masyarakat Madani (JPMM), 1(2), 162-178. https://doi.org/https://doi.org/10.21009/JPMM.001.2

Susantini, E., Rahayu, Y. S., Budiono, D., \& Raharjo, R. (2016). Profil Artikel Ilmiah Buatan Guru pada Pelatihan Penulisan Karya Ilmiah bagi Guru-Guru di SMP Lab School Surabaya. Jurnal Abdi: Media Pengabdian Kepada Masyarakat, 1(1), 1-7. https://doi.org/http://dx.doi.org/10.26740/ja.v1n1.p1-7 